\title{
PERANAN PERADILAN AGAMA DALAM PERTUMBUHAN DAN DINAMIKA HUKUM KEWARISAN DI INDONESIA
}

\author{
Oleh. Hamzah \\ Fakultas Syariah dan Hukum Islam, IAIN Bone, Indonesia \\ Email: hamzahlatif122@gmail.com
}

Article history:

Received: $17-08-2020$

Revised: $22-08-2020$

Accepted: $25-08-2020$

\section{Abstract}

This study examines the role of religious courts in the construction of Islamic inheritance law. Its urgency is to open the dimensions of birth and the growth of inheritance law in the development period of religious courts. In addition, it opens up concrete reasons for the existence of the inheritance law bill that has yet to reach a climax. The methodology in this study is a narrative literature study, with a historical approach by observing juridical aspects in the growth of inheritance law.

The findings in this study show that Islamic law existed since the era of the sultanate and was used as an applied law in society, including inheritance law that has been embedded in Islamic law. The authority of the religious judiciary in the field of inheritance became disoriented when the colonialists entered the colonies by applying the receptiveness theory as outlined in the form of the Staatsblad. The climax of the authority of the religious courts is the unification of the judiciary (one roof system) and its independence as the executor of judicial power. The challenge for religious courts in the field of inheritance is the unavailability of material law and the inheritance law bill which creates uncertainty.

\section{Keywords: Dynamics; Inheritance law; Religious Courts.}

\begin{abstract}
Abstrak
Kajian ini mengetengahkan peran peradilan agama dalam konstruksi hukum waris Islam. Urgensitasnya adalah membuka dimensi kelahiran dan pertumbuhan hukum waris dalam priodeisasi perkembangan peradilan agama. Di samping itu, membuka alasan konkret keberadaan RUU hukum waris yang belum mendapatkan titik klimaks. Metodologi dalam kajian ini adalah studi pustaka yang bersifat naratif, dengan pendekatan historis dengan mengamati aspek yuridis dalam pertumbuhan hukum waris.

Hasil temuan dalam kajian ini menujukkan bahwa, hukum Islam ada sejak era kesultanan dan dijadikan sebagai hukum terapan di masyarakat, termasuk hukum waris telah melekat dalam hukum Islam. Kewenangan peradilan agama dalam bidang waris menjadi tidak terarah disaat Kolonial masuk menjajah dengan menerapkan teori receptie yang dituangkan dalam bentuk Staatsblad. Puncak kewengan peradilan agama dengan terjadinya penyatuatapan badan peradilan (one roof system) dan independesinya sebagai pelaksana kekusaan kehakiman. Tantangan peradilan agama dalam bidang waris adalah ketidaktersedian hukum materil dan RUU hukum waris yang menuai ketidak-pastian.
\end{abstract}

Kata Kunci: Dinamika; Hukum Waris; Peradilan Agama. 


\section{A. Pendahuluan}

Peradilan agama merupakan lembaga peradilan yang berada dalam kekuasaan Mahkamah Agung. Hal itu disebutkan dalam Pasal 24 Ayat (2) UUD Negara Republik Indonesia tahun 1945. Kedudukan badan Peradilan Agama sejajar dengan Peradilan Negeri (umum), Peradilan Tata Usaha Negara (PTUN) serta Peradilan Militer. Sehingga kedudukan peradilan agama memiliki posisi yang kuat dalam aspek kewenangan, karena telah disejajarkan dengan peradilan lainnya dalam peraturan tertinggi dalam hierarki perundang-undangan. ${ }^{1}$

Secara khusus dalam UU No. 3 tahun 2006 Pasal 49 telah memberikan kewenangan peradilan agama untuk menyelenggerakan penegakan hukum dalam bidang produk hukum Islam. Di antara produk hukum Islam yang dapat diselesaikan di peradilan agama adalah persoalan warisan, wasiat dan hibah. ${ }^{2}$ Dalam UU No. 3 tahun 2006 telah memberikan kewenangan baru peradilan agama berupa sengketa ekonomi syariah. Namun yang paling penting dalam dinamika hukum waris, terjadi perubahan signifikan terhadap penyelesaian sengketa waris.

Sebagaimana dalam UU peradilan agama sebelumnya, yakni UU No. 7 tahun 1989 dalam penjelasanya telah memberikan opsi dalam penyelesaian persoalan waris, untuk dapat memilih hukum yang akan digunakan. Sementara dalam penjelasan UU No. 3 tahun 2006 penjelasan demikian telah dihapus. ${ }^{3}$ Hal itu membuktikan bahwa dinamika perubahan perundang-undangan tentang peradilan agama telah banyak berpihak kepada umat Islam. Maka demikian persoalan waris, baik permohanan pembagian warisan sampai pada sengketa waris bagi umat Islam harus diselesaikan di peradilan agama. ${ }^{4}$

${ }^{1}$ Mohd. Abdu A. Ramly, Kedudukan Peradilan Agama dalam Sistem Hukum Nasional (Akar, Sejarah, dan Perkembangannya) (Jakarta: Jurnal: Mimbar Hukum No. 59/2003), h. 30.

${ }^{2}$ Chatib Rasyid, Eksistensi Peradilan Agama Pasca UU No. 3 Tabun 2006 (Medan: Makalah dalam Kuliah Umum Acara Peresmian/pengukuhan Pengurus Ikatan Keluarga Magister Ilmu Hukum UMSU, 2007), h. 1.

${ }^{3}$ Chatib Rasyid, Eksistensi Peradilan Agama Pasca Undang-Undang..., h. 1.

4Syamsuhadi Irsyad, Eksistensi Peradilan Agama Pasca UU. No. 3 Tabun 2006 (Medan: Makalah dalam Acara Sosialisasi UU No. 3 Tahun 2006 tentang Perubahan atas UU No. 7 Tahun 1989 tentang Peradilan Agama, pada tanggal 22-23 Desember 2006), h. 9. 
Bukan hanya dalam perubahan perundang-undangan yang telah banyak memberikan kontribusi dalam pertumbuhan produk hukum Islam, namun peradilan agama telah memperkaya kajian keisalaman dalam bidang hukum keluarga Islam. Di samping itu, dalam perjalanan peradilan agama telah menorehkan banyak menghadirkan polemik sebagai catatan sejarah dalam perkembangan dan pertumbuhan peradilan agama. Bukan hanya dalam persoalan warisan, akan tetapi dalam masalah wasiat dan hibah telah banyak mendapat polarisasi untuk bisa sampai pada kewenangan peradilan agama.

Mempertimbangan dinamika peradilan agama dalam kewenangannya. Masalah waris, ternyata sebelumnya melahirkan dualisme penyelesaian hukum menjadi menarik untuk dikaji ulang. Kajian ulang tidak bermaksud studi histori semata, akan tetapi untuk melihat lebih jauh penggambaran peradilan agama dalam pertumbuhan dan dinamika hukum waris Islam di Indonesia. Hal itu urgen, mengingat tantangan hukum waris yang sampai sekarang belum mendapatkan titik terang dalam pembentukan perundang-undangan tentang waris. Di samping itu, hukum waris dan wasiat masih diatur dalam Inpres No. 1 tahun 1991 tentang Kompilasi Hukum Islam (KHI), yang sebagaimana diketahui bahwa Inpres tidak termasuk dalam hierarki perundang-undangan. Untuk itu kajian ini, di samping melakukan studi histori juga memcoba mencari informasi akan peran peradilan dalam pertumbuhan dan perkembangan produk hukum Islam dalam bidang waris.

\section{B. Pembahasan}

\section{Dinamika Kewenangan Peradilan Agama: Dalam Bingkai Sejarah}

Peran peradilan ${ }^{5}$ agama merupakan pengadilan negara Republik Indonesia yang mempunyai wewenang dalam pelaksanaan kekuasaan kehakiman. Secara yuridis dalam UU No. 7 tahun 1989 jo. UU No. 3 tahun 2006, telah disebutkan dalam Pasal 2 bahwa "peradilan agama merupakan salah satu pelaksana kekuasaan kehakiman bagi rakyat pencari keadilan yang beragama Islam

${ }^{5}$ Peradilan dan pengadilan, urgen untuk memberikan penjelasan atas perbedaan kedua istilah itu. Pertama, peradilan sebagai pranata (institution) dalam memenuhi kepentingan masyarakat dalam penegakan supremasi hukum dan dalam memperoleh keadilan, yang berpedoma terhadap ketentuan hukum yang berlaku. Sedangkan pengadilan merupakan organisasi (institute) yang menyelenggarakan penegakan supremasi hukum dan keadilan. Lihat, Cik Hasan Bisri, Peradilan Islam dalam Tatanan Masyarakat Indonesia (Cet. Bandung : Renaja Rosdakarya, 1997), h. 36. 
mengenai perkara tertentu yang diatur dalam Undang-undang ini”. Dalam UU No. 7 tahun 1989 menyebutkan "perkara perdata", sementara dalam UU No. 3 tahun 2006 sebagai hasil revisi menyebutkan "perkara tertentu", sebagai penjabaran kewenangan yang disebutkan dalam Pasal 49.

Dalam Pasal 49 kompetensi peradilan agama disebutkan bahwa "Pengadilan Agama bertugas dan bewenang memeriksa, menugaskan dan mengadili, perkara-perkara di tingkat pertama antara orang-orang yang beragama Islam di bidang perkawinan, kewarisan, wasiat, dan hibah, wakaf dan sedekah. ${ }^{6}$ Sebagai tambahan dalam UU No. 3 tahun 2006, ditambahkan ekonomi syariah. ${ }^{7}$ Hal itu memperlihatkan peran peradilan agama dalam membidangi serangkaitan persoalan hukum Islam telah diperluas. Penambahan dalam bidang ekonomi syariah merupakan respon atas hadirnya berbagai produk-produk yang berbasis syariah.

Kewenangan yang menjadi sifat dari peradilan itulah turut menjadi perannya. Dalam peradilan, kewenangan atau kompetensi adalah sesuatu yang berbeda dimiliki oleh setiap peradilan, dan kewenangan itu sifatnya absolute atau memaksa. Ketatapan atas kewenangan, kekuasaan atau kompetensinya menjadi hal mutlak bagi lingkungan peradilan dalam melakukan perannya berupa memeriksa, memutus dan menyelesaikan. Dalam istilah tertentu kewenangan peradilan telah banyak diistilahkan baik itu kompetensi absolut, yuridiksi absolut dan kadang disebut kekuasaan mutlak (Absolute Competentie).

Sebaliknya, perkara yang tidak termasuk dalam bidang kewenangannya, secara absolut tidak memiliki wewenang untuk mengadilinya. Tujuan penentuan batas kewenangan peradilan dalam pelaksanaan kekuasaan kehakiman adalah menertertibkan masing-masing kewenangan lingkungan peradilan. Keinginan untuk masing-masing peradilan berjalan dan melalui garis koordinat yang telah ditetapkan oleh UU dengan tidak saling berebut kewenangan. Bergerak dan berfungsi masing-masing peradilan dengan batas kewenangan yurisdiksi yang telah ditetapkan berdasarkan ketentuan perundang-undangan.

${ }^{6}$ Undang-Undang No. 7 Tahun 1989, h. 73-74.

7Undang-Undang No. 3 Tahu 2006 Pasal 49. 
Kewenangan mengadili lingkungan peradilan agama ditentukan oleh dua faktor yang menjadi ciri keberadaannya. Pertama, perkara tertentu di antaranya; perkawinan, warisan, wasiat, hibah, wakaf dan sedekah); dan kedua, golongan masyarakat, rakyat dan atau warga negara tertentu yakni yang beragama Islam. Dalam garis besar kewenangan peradilan agama yang ditetapkan dalam UU No. 3 Tahun 2006, yang sejalan dengan ketentuan UU pokok-pokok kekuasaan kehakiman yang menggariskan kompetensi peradilan agama. Melalui penggolongan dalam bidang perkara yang telah diperluas dalam bidang ekonomi syariah.

Peradilan agama di Indonesia telah tumbuh dan berkembang seirama dengan pertumbuhan serta perkembangan masyarakat Islam dan hukum Islam di Indonesia. Puncak perkembangan peradilan agama terlihat di era terbentuknya kerajaan-kerajaan Islam di bumi nusantara. Setelah kekuasaan pemerintah Belanda menancapkan kakinya di bumi nusantara, keberadaan peradilan agama di Indonesia menurun seirama dengan perkembangan politik hukum pemerintah kolonial sebelum abad ke-20 (dua puluh). Politik hukum pemerintah kolonial Belanda berdasarkan dari teori resepsi in Complexu, yang digagas oleh Van Den Berg dengan memperhatikan hukum yang hidup (living law) di tengah masyarakat Indonesia adalah kekuatan Islam, sehingga hukum Islam diberlakukan. ${ }^{8}$

Namun keadaan itu tidak bertahan lama, setelah praktek hukum pemerintah kolonial mendasarkan diri atas teori receptie yang digagas oleh Christian Snouck Horgronye. Teori receptie Snouck membenturkan antara hukum Islam dan adat, pemberlakuan hukum Islam harus sejalan dengan adat, sehingga posisi hukum adat lebih tinggi ketimbang hukum Islam. Kecerdasan Snouck dalam menawarkan teori receptie tidak lain adalah kekhawatiran akan terjadinya gerakan penyatuan kekuatan Islam yang dapat mengecam keberlangsungan Belanda di Indonesia. ${ }^{9}$ Hal itu membuat Snouck untuk menawarkan pemberlakuan teori receptie bukan sekadar kedudukan Islam sebagai kepercayaan atau agama,

${ }^{8}$ H. Taufiq, Prospek Peradilan Agama (Makassar: Makalah Seminar Nasional dan Kongres I Forum Mahasiswa Syari'ah Se Indonesia, 1996), h. 2-3.

${ }^{9}$ Daliar Noer, The Modernist Muslim Movement in Indonesia 1900-1942 (London: KL: 1973), h. 164. 
melainkan Islam menjadi jalan dalam memuluskan doktrin untuk melawan Belanda. ${ }^{10}$

Pemberlakuan teori receptie oleh Snouck diakhir abad XIX, dianggap melemahkan hukum Islam dan bahkan menyingkirkan hukum Islam dengan hukum adat. Maka tidak heran dengan gemah Prof. Hazairin menyebut teori Snouck sebagai teori iblis. ${ }^{11}$ Sebagai penguatannya, Hazairin melahirkan teori receptive exit artinya keluar dari teori receptie Snouck, karena sudah dianggap tidak relevan dengan kondisi masyarakat Indonesia dan semangat UUD 1945. Sehingga ketentuan aturan peralihan tidak dapat dipergunakan dalam pemberlakuan teori receptie. Maka sebagai tindaklanjutnya telah lahir teori yang digagas oleh Sajuti Thalib murid dari Prof Hazairin, ${ }^{12}$ yakni teori receptive a contrario dalam pemahama bahwa hukum adat baru dapat berlaku ketika sejalan dengan hukum Islam.

Pada hakikatnya pengaruh teori receptie merupakan hukum adat yang berkuasa, sehingga eksistensi peradilan agama menurun disaat itu. Kenyataan sejarah dari pemberlakuan teori sistem hukum tentang peradilan agama bahwa; (1) Peradilan agama tumbuh dan berkembang seiring dengan pertumbuhan dan perkembangan masyarakat Islam; (2) Eksistensi pertumbuhan dan kewenangan peradilan agama dipengaruhi oleh politik hukum negara dalam memformulasikan produk hukum.

Pasca kemerdekaan, di tahun 1948, Negara Indonesia melakukan pembinaan peradilan agama dengan membentuk UU No. 19 tahun 1948. UU itu tetap mengakui eksistensi peradilan agama tetapi mengintegrasikan ke dalam Pengadilan Negeri. Namun UU tersebut tidak pernah dilaksanakan, karena takut menimbulkan konflik masyarakat Islam. Lahirnya UU No. 14 tahun 1970 telah mengakui keberadaan peradilan agama sebagai salah satu pelaksana kekuasaan kehakiman. Pada tahun 1977 peraturan Mahkamah Agung No. 1 tahun 1977

\footnotetext{
${ }^{10} \mathrm{Jamal}$ Jamil, Peradilan Agama di Indonesia Historya of Existence (Jurnal Al-Qada'u: Peradilan dan Hukum Keluarga Islam, Vol. 5 No. 1 Juni 2018), h. 17.

${ }^{11}$ Andi Nuzul, Sistem Hukum Kewarisan Bilateral Hazairin dan Pengarubnya terhadap Pembaruan Hukum Kewarisan di Indonesia (Cet. I; Yogyakarta: Trussmedia Grafika, 2018), h. 50.

${ }^{12}$ Andi Nuzul, Sistem Hukum Kewarisan Bilateral Hazairin, h. 50.
} 
mengintegrasikannya ke dalam sistem peradilan nasional, dengan dikategorinya kasasi perkara-perkara perdata agama yang berasal dari peradilan agama. ${ }^{13}$

Setelah pelaksanaan politik hukum Pancasila, dan pengetahuan dan serta pengahayatan agama minat Islam Indonesia mantap. Pembinaan peradilan agama mencapai puncaknya dengan diundangkannya UU No. 7 tahun 1989 tentang peradilan agama. Hal itu menandakan posisi peradilan agama semakin baik dari sebelumnya, namun secara organisasi, administrasi dan finansial masih berada di bawah wewenang departemen atau kementerian masing-masing.

Posisi peradilan agama semakin membaik dengan terjadinya penyatuatapan (one roof sistem) badan peradilan di bawah Mahkamah Agung. Hal itu dirumuskan dalam UU No. 4 tahun 2004 tentang kekuasaan kehakiman. Peradilan agama telah beralih secara organisasi, administrasi dan finansial di dalam lembaga Mahkamah Agung sesuai dengan Keppres Nomor 21 tahun 2004 tentang Pelaksanan Pengalihan Urusan Organisasi, Administrasi dan Finansial Lembaga Peradilan ke Mahkamah Agung, Pasal 2 Ayat (2). Sekaligus menjadi catatan berpisahnya peradilan agama dari kementerian agama sebagai pelaksana kekuasaan kehakiman. ${ }^{14}$ Hal itu disesuaikan dengan hasil amandemen UUD 1945 yang mengatur tentang kekuasaan kehakiman.

Di tahun 2006 peradilan agama, kembali mendapatkan amanah dalam kewenangan, dengan lahirnya UU No. 3 tahun 2006 tentang Peradilan agama. Secara garis besar peradilan agama diberikan kewenangan untuk menyelesaikan persoalan sengketa ekonomi syariah. Dan perubahan keduanya UU No. 50 tahun 2009 yang dengan eksistensi kewenangan hukum acara dan hukum terapannya telah semakin mapan. Peradilan agama menjadi pelaksana kekuasaan kehakiman secara konstitusional posisinya semakin kuat. Peradilan agama tidak hanya diakui dalam konstitusi Undang-Undang Dasar Negara Republik Indonesia tahun 1945, akan tetapi juga diakui penuh dalam UU No. 4 tahun 2004 yang telah diubah dalam UU No. 48 tahun 2009 tentang kekuasaan kehakiman, sehingga tidak hanya

${ }^{13}$ H. Taufiq, Prospek Peradilan Agama, h. 2-3

${ }^{14}$ Malik Ibrahim, Peradilan Agama di Era Orde Baru dan Reformasi Suatu Studi Perbandingan (Jurnal: Supremasi Hukum Vol. 4, No. 2, Desember 2015), h. 320. 
status dan kedudukan yang telah mengalami perubahan, namun kewenangannya telah bertambah. ${ }^{15}$

Hiruk-pikuk peradilan agama dalam perkembangannya telah banyak dipengaruhi oleh teori pemberlakuan hukum di masa kolonial. Seiring dengan proklamasi kemerdekaan Indonesia, peradilan agama terus mengalami perubahan, baik dalam sistemnya dan kedudukannya sebagai lembaga peradilan. Awal sejarah kebangkitan peradilan agama dengan lahirnya UU No. 7 tahun 1989 tentang peradilan agama. Meskipun dengan lahirnya UU, itu belum merdeka secara organisasi, administrasi dan finansial, namun secara yuridis peradilan agama telah mendapatkan pengakuan khusus dalam UU. Puncak dari pengakuan dari peradilan agama adalah lahirnya UU No. 4 tahun 2004 tentang kekuasaan kehakiman yang telah melakukan penyatuatapan (one roof system) badan peradilan di bawah Mahkamah Agung.

\section{Peranan Peradilan Agama: Dinamika Pertumbuhan Hukum Waris}

Salah satu bahagian terpenting dalam integrasi tata hukum di Indonesia adalah pengakuan hukum Islam. Menelik sejarah, di era kerajaan-kerajan Islam, ada di antaranya menjadikan hukum Islam sebagai hukum resmi. Semisal kerajaan Mataram, disaat Sultan Agung memegang kuasa, melakukan perubahan mendasar dengan menjadikan hukum Islam sebagai hukum terapan yang resmi diberlakukan di seluruh kerajaan Mataram. Pemberlakuan itu dimulai sejak berdirinya kerajaankerajaan Islam sampai dengan datangnya Kolonial Belanda dan membentuk Vereenigde Oost-Indische Compagnie (VOC) di Indonesia. ${ }^{16}$

Kehadiran hukum Islam dimasa kerajaan diperkuat dengan pemberlakuan teori receptie in complexu di awal masuknya kolonial, karena pertimbangan hukum yang hidup dan melekat di masyarakat Indonesia adalah hukum Islam. Di masa kerajaan kesultanan telah terbentuk badan peradilan yang mempunyai fungsi pelaksanaan kehakiman.

15Muhammad Derobi, Analisis UU No. 7 Tahun 1989, UU No. 3 Tahun 2006 dan UU No. 50 Tabun 2009 (Makalah UIN Syarif Hidayatullah, Jumat 24 Mei 2013), h. 15.

${ }^{16}$ Vereenigde Oost-Indische Compagnie (VOC) merupakan badan serikat dagang para pedagang Belanda di Indonesia berdiri tahun 1602 M. Lihat Taufiq Hamimi, Ikbtisar Sejarah Peradilan Agama di Indonesia (Mimbar Hukum, No. 59 Thn. XIV, 2003), h. 18. 
Dasar hukum dalam peradilan Islam di masa kerajaan dengan memakai hukum acara peradilan Islam (mukhsamat). Pendekatan syariat Islam dalam menyelesaikan persoalan menjadi hal yang sangat dianjurkan di masa kerajaan. Penerapan hukum waris dengan mempertimbangkan hukum yang hidup dan sekaligus mengelaborasi dengan budaya yang berkembang di tengah masyarakat. Strategi pelaksanaan peradilan di masa kesultanan cukup berhasil dalam menyelesaikan perkara-perkara kewarisan bagi umat Islam. ${ }^{17}$

Keberhasilan Belanda dalam menjajah Indonesia adalah buah dari terbentuknya VOC. Berbagai upaya-upaya konkret untuk menjauhkan orang Islam dari keislamanya. Salah satu upaya efektif dari Belanda untuk menjauhkan orang Islam dari keislamannya dengan menjauhkan dari hukum Islam. ${ }^{18}$ Upaya itu dapat terlihat dari pemberlakuan teori recetie yang diusulkan oleh Snouck. Efeknya dalam peradilan agama berupa pencabutan kekuasaan atau kewenangan peradilan agama. Penyelesaian sengketa dalam hukum Islam, khususnya masalah waris telah dicabut dari kewenangan peradilan agama. Sehingga saat itu, peradilan agama hanya menyelesaikan persoalan yang terkait dengan hukum keluarga atau perkawinan.

Kecerdikan Kolonial dan menghambat pertumbuhan hukum waris dengan pemberlakuan teori receptive dalam penerapan hukum. Termasuk kewenangan peradilan agama dalam masalah waris terus dibatasi dan bahkan dialihkan. Salah satu yang bisa dilihat dalam kewenangan pengadilan agama di Jawa dan Madura. Perubahan Staatsblad 1937 No. 116 dan No. 610, yang telah mengalihkan kewenangan peradilan agam dalam masalah warisan ke peradilan umum. Hal itu didasarkan atas pertimbangan hukum waris tidak menjadi hukum adat. ${ }^{19}$ Padahal di masa kesultanan hukum Islam dielaborasi dengan hukum adat tanpa membenturkan keduanya.

${ }^{17}$ A. Rahmad Rosyadi dan M. Rais Ahma, Formaolasi Syari'at Islam dalam Perspektif Tata Hukum Indonesia (Bogor: Ghalia Indonesia, 2006), h. 74.

${ }^{18}$ Sayuruddin Daulay, Positivisasi Hukum Islam di Indonesia dalam Perspektif Politik Hukum (AnalisaTerhadap Hukum Perkawinan) (Medan: Tesis Program Pasca Sarjana UMSU, 2006), h. 5.

${ }^{19}$ Iim Fahimah, Sejarah Perkembangan Hukum Waris di Indonesia (Jurnal Nuansa Vol. XI, No. 2, Desember 2018 ), h. 111. 
Pasca kemerdekaan Indonesia pada tanggal 17 Agustus 1945 telah memberikan harapan besar bagi bangsa Indonesia secara umum dan khusus bagi peradilan agama sendiri sebagai bagian dari negara. Tidak banyak yang bisa dilakukan Pasca kemerdekaan, namun terpenting adalah pengesahan dasar negara, sehingga panitia sembila bersidang dan mengesahkan UUD 1945. Dalam Pasal II Aturan Peralihan dalam UUD 1945 disebutkan bahwa hukum kolonial tetap berlaku selama tidak bertentangan dengan jiwa UUD. Termasuk dalam teori penerapa hukum, receptie menurut Hazairin dianggap tidak berlaku, di samping memiliki kesenjangan dengan UUD, pemberlakuan teori receptie juga bertentangan dengan nash al-Qur'an dan hadis. ${ }^{20}$

Secara konstitusional peradilan agama berakhir sebagai peradilan semu, sejak lahirnya UU. No. 14 tahun 1970 tentang Pokok-Pokok Kekuasaan Kehakiman. Dalam UU No. 14 tahun 1970 di Pasal 10 telah menyebutkan kekuasaan kehakiman dilakukan oleh empat peradilan, dan salah satunya adalah peradilan agama. Perwujudan dari UU itu dipertegas dengan lahirnya UU. No. 7 tahun 1989 Tentang Peradilan Agama yang secara yuridis formal telah memposisikan peradilan agama sejajar dengan badan-badan peradilan lainnya, seperti peradilan umum, peradilan tata usaha Negara dan peradilan militer. ${ }^{21}$

Peradilan agama tidak hanya sebatas lembaga pelaksana kekuasaan kehakiman, akan tetapi peradilan telah memberikan kontribusi dalam pertumbuhan hukum waris. Dinamika peraturan peradilan agama telah membawa kontribusi sendiri dalam bingkai aturan kewarisan. Pertumbuhan hukum waris tidak bisa dilepas dari pertumbuhan peradilan agama, sebagai lembaga yang mempunyai fungsi pelaksana kekuasaan kehakiman.

Masalah kewarisan telah menjadi kompetensi dan wewenang peradilan agama. Hal itu tertuang dalam penjelasan UU No. 3 tahun 2006 Pasal 49 huruf (b). Secara subtansi dalam UU itu mengatur tentang siapa yang berhak untuk menjadi ahli waris; harta peninggalan pewaris; porsi atau bagian hak dari para ahli

${ }^{20}$ A. Rahmad Rosyadi dan M. Rais Ahma, Formaolasi Syari'at Islam, h. 76.

${ }^{21}$ Satjipto Rahardjo, Pengadilan Agama Sebagai Pengadilan Keluarga, dalam Amrullah et.al. (ed), Prospek. Hukum Islam dalam Kerangka Pembangunan Hukum Nasioal di Indonesia (Jakarta: PP. IKAHA, 1994), h. 301. 
waris; pelaksanaan pembagian harta yang ditinggalkan (tirkah); dan penetapan pengadilan terhadap permohonan penentuan ahli waris dan penentuan pembagian hak para ahli waris. ${ }^{22}$

Peran serta peradilan agama dalam pertumbuhan hukum waris, terdapat dalam UU No. 7 tahun 1989 tentang peradilan agama. Dalam UU itu telah menyebutkan bahwa para pihak yang akan melakukan sengketa atau permohonan pembagian warisan, dapat memliki hukum yang akan digunakan. Maknanya adalah dalam pembagian warisan dan sengketa warisannya, ada dua hukum yang dapat digunakan atau dapat mempertimbangkan untuk memilih hukum. Ketentuan itu termuat dalam penjelasan Pasal 49 huruf b UU No. 7 tahun 1989 bahwa "Para pihak sebelum berperkara dapat mempertimbangkan untuk memilih hukum apa yang digunakan dalam pembagian warisan". ${ }^{23}$ Ketentuan dalam Pasal 49 huruf b itu telah dihapus, dengan demikian telah memiliki landasan hukum kuat dalam persoalan sengketa waris dilimpahkan sepenuhnya ke peradilan agama. ${ }^{24}$

Dalam Pasal 50 UU No. 7 tahun 1989 menyebutkan bahwa dalam perkara sengketa hak milik atau keperdataan lainnya. Sebagaimana dalam Pasal 49 secara khusus dalam objek sengketa harus diselesaikan terlebih dahulu di peradilan umum. Artinya campur tangan peradilan umum harus tetap ada dalam hal objek waris itu ternyata sengketa hak milik. Kendala dalam pengembalian kewenangan peradilan agama dalam sengketa waris menimbulkan dualisme hukum. Redaksi dalam Pasal 49 secara jelas memberikan hak untuk memilih dalam penyelesaian sengketa waris, baik di peradilan agama dan atau di peradilan umum. Sehingga ada pertimbangan yang diberikan kepada pihak-pihak dalam penyelesaian sengketa waris.

Ketentuan dalam Pasal 49 UU No. 7 tahun 1989 terkait dengan dualisme hukum dalam penyelesaian sengketa waris telah dilakukan pembaharuan dan penambahan ayat untuk memaksimalkan peran peradilan agama terhadap kaum

22Undang-Undang No. 3 Tahun 2006 Pasal 49 Huruf b.

23Undang-Undang No. 7 Tahun 1989 Pasal Pasal 49.

${ }^{24}$ Syamsuhadi Irsyad, Eksistensi Peradilan Agama Pasca UU. No. 3 Tahun 2006 (dalam Acara Sosialisasi UU No. 3 Tahun 2006 tentang Perubahan atas UU No. 7 Tahun 1989 tentang Peradilan Agama (Medan, tanggal 22-23 Desember 2006), h. 9. 
muslimin. Dengan diundangkannya UU No. 3 tahun 2006 tentang peradilan agama, kalimat yang mengindikasikan pilihan hukum tersebut telah disempurnakan dengan memberikan penegasan bahwa bagi sesama umat Islam bisa sekaligus melakukan penyelesaian sengketa hak milik di peradilan agama. Dengan demikian sengketa kewarisan kini mutlak diselesaikan berdasarkan hukum Islam di peradilan agama bagi yang beragama Islam. ${ }^{25}$

Namun dalam perubahannya dalam UU No. 3 tahun 2006 di Pasal 50 tetap menyebutkan hal yang sama, namun secara signifikan ada penambahan ayat (2) dalam Pasal ini bahwa, apabila terjadi sengketa hak milik yang subjek hukumnya antara orang-orang yang beragama Islam, maka objek sengketa tersebut diputus oleh pengadilan agama. Sehingga dalam UU No. 3 tahun 2006 memberikan opsi jelas, bahwa meskipun ada sengketa hak milik akan tetapi yang bersengkata adalah sama-sama beragama Islam maka diselesaikan di peradilan agama. Penetapan peradilan umum dibutuhkan apabila yang bersengketa itu salah satunya tidak beragama Islam.

Sejak lahir UU. No. 3 tahun 2006, kewenangan atau kekuasaan mengadili sengketa warisan antara orang-orang beragama Islam tidak lagi mempunyai dualisme hukum. Kewenangan mutlak peradilan agama untuk mengadili perkara warisan bagi yang beragama Islam. Sumber hukum materil dengan basis hukum Islam yang bermuara pada sumber primer hukum Islam yakni al-Qur'an dan hadis. Sumber pokok itu kemudian dijabarkan dalam kitab-kitab fikih dan diformulasikan dalam bentuk peraturan perundang-undangan. Salah satu produk hukum materil peradilan agama yang digunakan adalah Kompilasi Hukum Islam (KHI). Hukum waris Islam menjadi salah satu muatan dari KHI. Dikatakan sebagai hukum waris Islam karena di dalamnya memuat suatu ilmu tentang kewarisan, baik yang menerima, yang tidak menerima pusaka, kadar warisan dan cara pembagiannya. ${ }^{26}$

Kehadiran KHI menjadi wujud dari penguatan hukum waris Islam, dan secara umum membicarakan aspek-aspek dari hukum Islam di Indonesia. 
Perbincangan tersebut merupakan perbincangan yang kompleks, sekalipun hukum Islam menempati posisi yang sangat penting dalam kehidupan berbangsa dan bernegara. ${ }^{27}$ KHI dianggap sebagai satu di antara sekian banyak karya besar dalam rangka memberi arti yang lebih positif bagi kehidupan dan kebangkitan peradilan agama. Kompilasi Hukum Islam tidak bersifat mutlak atau sesuatu yang telah final. KHI bersifat lebih terbuka dalam menerima usaha-usaha perbaikan dan penyempurnaan untuk meraih keberhasilan yang lebih baik di masa mendatang. ${ }^{28}$ Karena seperti diketahui posisi KHI masih dalam bentuk Inpres yang belum begitu kuat dalam tatanan hukum di Indonesia, namun muatan dalam KHI sudah disesuaikan dengan kultur masyarakat Indonesia.

\section{Tantangan Peradilan Agama: Legislasi Hukum Waris}

Tantangan terbesar peradilan agama telah dilalui di era penjajahan Kolonial Belanda, khusus dalam persoalan kewarisan yang sempat dipisahkan dari kompetensi peradilan agama. Hingga sampai pada era reformasi dan sampai sekarang ternyata posisi hukum waris yang dimuat dalam KHI dianggap masih belum mempunyai kekuatan memadai dalam bingkai hukum di Indonesia. Padahal KHI sudah menjadi rujukan hakim di peradilan agama dalam memutuhkan masalah perkawinan, kewarisan dan lainnya.

Pada awalnya KHI akan diperjuangkan menjadi undang-undang hukum materiil di peradilan agama. Akan tetapi karena kondisi politik yang belum memungkinkan akhirnya KHI disahkan dengan inpres Nomor 1 tahun 1991 pada tanggal 10 Juni 1991. KHI telah dipedomani di peradilan agama bahkan di Kantor Urusan Agama (KUA). Hal itu menjadi formulasi hukum Islam sebagai tatanan hukum yang dipegangi/ditaati oleh hakim dan mayoritas penduduk rakyat Indonesia. Hukum yang hidup dalam masyarakat, sebagian dari ajaran dan keyakinan Islam dan ada dalam kehidupan hukum nasional dan merupakan bahan dalam pembinaan dan pengembangannya. ${ }^{29}$ KHI menjadi hukum Nasional, yang

\footnotetext{
${ }^{27}$ Saekan dan Erniati Effendi, Sejarah Penyusunan Kompilasi Hukum Islam di Indonesia (Surabaya : Arkola, 1997), h. 9.

${ }^{28}$ Abdurrahman, Kompilasi Hukum Islam di Indonesia (Jakarta: Akademika Pressindo, 1992), h. 5-8.

${ }^{29}$ M. Daud Ali, Asas-asas Hukum Islam (Jakarta : Rajawali Press, 1986), h. 189.
} 
sumbernya dari hukum Islam yang telah disesuaikan dengan kultur masyarakat Indonesia.

Namun, yang menjadi pertanyaan besar adalah kedudukan KHI dalam hukum Nasional. Ada tiga buku dalam muatan KHI, namun hukum waris belum mendapatkan titik terang dalam legislasi UU. Buku tentang nikah dalam KHI, yang secara tersendiri diatur dalam UU No. 1 tahun 1974, buku tentang wakaf dalam KHI telah diundangkan UU No. 41 tahun 2004. Sementara buku tentang waris belum memperlihatkan tanda-tanda legislasinya.

Penyusunan RUU hukum materil peradilan agama bidang hukum kewarisan yang kemudian disahkan menjadi peraturan perundang-undangan merupakan suatu langkah konkret, maju dan penguatan dalam memenuhi kebutuhan umat Islam di Indonesia. Msekipun dalam penyusunan RUU hukum waris harus memperhatikan nilai-nilai hukum kewarisan yang hidup dan berkembang pada setiap suku bangsa yang beragama Islam di Indonesia dari masa ke masa. Peraturan perundang-undangan yang berkenaan hukum kewarisan Islam dapat dianggap baik bila memenuhi unsur hukum di dalam teori-teori ilmu hukum mengenai berlakunya hukum sebagai kaidah. Dan hukum waris menjadi kebutuhan dalam rujukan dalam penyelesaian sengketa waris di peradilan agama. Kendatipun tidak mengesampingkan ijtihad hakim dalam menetapkan putusannya.

Dalam aspek teoretis dalam pembaharuan hukum waris di Indonesia cukup memadai, mengingat Hazairin sebagai pembaharu hukum waris Islam yang pertama kali menyoal teori waris bilateral. Disusul oleh Munawir Sadzali yang telah mengagas reaktualisasi hukum Islam. Hazairin berpendapat bahwa nash dalam al-Qur'an yang mengatur tentang waris menginginkan cita-cita hukum waris yang bilateral. Pemahaman Hazairin dalam memahami nash-nash tentang kewarisan dalam konteks pemberlakuannya tidak secara umum, akan sifatnya kasusistik atau berlaku temporal. ${ }^{30}$

Pendapat yang cukup kontekstual, dikemukakan oleh Munawir Sadzali yang secara tegas memberikan kritikan akan bahagian dari hak waris perempuan 
yang separuh dari laki-laki, yang sudah dianggap tidak relevan lagi dnegan zaman. ${ }^{31}$ Pemahaman itu lebih kepada penyesuaian dengan perkembangan zaman serta kultur masyarakat. Sehingga pola perkembangan hukum waris Islam dengan mudah diterima di tengah masyarakat.

Di samping teori-teori di atas, masih banyak yang menjelasakan tentang kewarisan Islam. Namun, dalam pembentukan RUU hukum waris banyak menuai konflik dalam proses legislasinya. Budaya dan kultur masyarakat selalu menjadi pertimbangan dalam pengesahan hukum waris Islam. Di samping itu, penafsiran nash-nash tentang hukum waris masih sangat normatif sehingga sarat akan perbedaan porsi laki-laki dan perempuan. Maka tidak heran dalam pembagian warisan lebih mengedepankan pembagian warisan berdasarkan musyawarah dan adat masyarakat. Bangsa Indonesia adalah bangsa bermartabat mempunyai budaya, adat-istiadat yang mencerminkan kepribadiaan, kemudian menjadi sumber hukum Adat. $^{32}$ Kendatipun ada yang berpendapat bahwa hukum adalah hasil peninggalan dan ciptaan Kolonial Belanda. ${ }^{33}$ Hukum adat dihadirkan untuk memecah belah masyarakat di kalangan muslim dengan orang masuk dalam kategori Nasionalis. $^{34}$

Rasa keadilan harus dijadikan pertimbnagan dalam pembangunan hukum waris Islam di Indonesia. Kultur masyarakat harus dipertimbangkan dalam perumusan hukum waris, karena hal itu menjadi corak tersendiri dari masyarakat Indonesia yang kaya akan budaya dan adat. Kendatipun demikian belum dapat diwujudkan, mengingat keberagaman konsep rasa keadilan lokal berbeda-beda. Hal serupa dialami pembanguna hukum Islam yang berwawasan ke-Indonesiaan. Pembangunan hukum Islam hanyak dapat dilakukan dengan pendekatan hukum

${ }^{31}$ Munawir Sjadzali, Dari Lembah Kemiskinan, dalam Muhammad Wahyuni Navis (ed.), Kontektualisasi Ajaran Islam (Jakarta: Paramadina, 1995), h.87-96.

${ }^{32}$ Soeroyo Wignyodipoero, Pengantar dan asas-Asas Hukum Adat (Jakarta: Gunung Agung 1995), h. 13.

${ }^{33}$ M.A. Jaspan, Mencari Hukum Baru Sinkretisme Hukum di Indonesia yang Membingungkan, dalam Mulyana W. Kusumah (ed), Hukum Politik dan Perubahan Sosial (Jakarta: Yayasan Lembaga Bantuan HUkum Indonesia, 1988), h. 240.

${ }^{34}$ Amrullah Ahmad, Prospek Hukum Islam dalam Kerangka Pembangunan Hukum Nasional di Indonesia, Sebuah Kenangan 65 Tahun Bustanul Arifin (Jakarta: Ikaha Jakarta, 1994), h. 6. 
secara abstrak dan konkrit. Pendekatan hukum secara abstrak dengan melalui legislasi, sedangkan pendekatan hukum secara konkret dapat diwujudkan melalui putusan peradilan, dengan mempertimbangkan rasa keadilan lokal. Sehingga dalam setiap merumuskan hukum secara abstrak sedapat mungkin memberikan ruang kepada hakim untuk memberikan keputusan dengan rasa keadilan lokal. ${ }^{35}$

Inilah yang menjadi tantangan terbesar dalam peradilan agama era sekarang, karena tidak tersediaanya aturan yang konkret dalam masalah warisan maka maka hakim kerja ekstra dalam pemecahan sengketa waris. Maka tidak heran dalam persoalan-persoalan waris putusan hakim sangat bervariatif dan terbuka ruang untuk melahirkan yurisprudensi. Sikap positif yang dapat diambil adalah progresifitas hakim, serta kontribusi pemikiran dan keilmuannya akan sangat diharapkan dan dapat diaktualisasikan melalui ruang terbuka itu. Oleh karena itu, dalam tantangan peradilan agama berupa ketersediaan produk hukum waris yang memadai, sebagai rujukan dalam pelaksanaan kekuasaan kehakiman.

\section{Penutup}

Peradilan agama cukup esksis dalam kultur masyarakat Indonesia di era kesultanan, karena peradilan agama menjadi hukum terapan, begitupun dengan hukum waris. Kehadiran penjajah, telah mendiskreditkan hukum waris Islam dari ruang peradilan agama. Hal itu dilakukan Kolonial Belanda, dalam upaya menghindari lahirnya doktrin melalui lembaga keagamaan yang berakibat pada perlawana kepada penjajah. Namun, eksistensi peradilan perlahan membaik seiring dengan terwujudnya kemerdekaan. Peran peradilan agama sebagai lembaga pelaksana kekuasaan kehakiman telah diatur dalam penetapan kewenangan atau kompetensi peradilan. Wujud nyata kehadiran peradilan agama dengan lahirnya UU No. 7 tahun 1989, sebagai tangga pertama kiprah peradilan agama di Indonesia.

Kekuatan peradilan agama menjadi semakin kuat dengan lahirnya UU No. 4 tahun 2004 yang telah memberikan kewenangan peradilan agama secara independen untuk melaksanakan fungsinya dalam organisasi, administrasi dan

\footnotetext{
${ }^{35}$ Kementerian Agama RI, Problematikan Hukum Kewarisan Islam Kontemporer di Indonesia (Cet. I; Jakarta: Badan Litbang dan Diklat Puslitbang Kehidupan Keagamaan, 2012), h. 68.
} 
finansial. Kekuatan peradilan semakin mantap dengan lahirnya UU No. 3 Tahun 2006 tentang peradilan agama yang secara saksama menetapkan bahwa perkara waris (termasuk hak milik) bagi umat Islam diselesaikan di peradilan agama. Dalam konstruksi hukum waris telah diatur dalam inpres No. 1 Tahun 1991 tentang KHI menjadi hal positif di era orde baru, namun menjadi tanda tanya di era sekarang. Keberadaan RUU hukum waris belum mendapatkan titik terang dalam aspek legislasinya, banyak faktor yang menjadi penghambat salah satunya adalah kultur masyarakat Indonesia pluralis. Hal itu menjadi tantangan tersendiri lembaga peradilan dalam pemenuhan hukum materil kewarisan, karena hakim diberikan ruang untuk melakukan penyelesaian sengketa waris dengan keterbatasan peraturan perundang-undangan.

\section{DAFTAR PUSTAKA}

Abdurrahman. Kompilasi Hukum Islam di Indonesia. Jakarta: Akademika Pressindo, 1992.

Ali, M. Daud. Asas-asas Hukum Islam. Jakarta: Rajawali Press, 1986.

Ahmad, Amrullah. Prospek Hukum Islam dalam Kerangka Pembangunan Hukum Nasional di Indonesia, Sebuah Kenangan 65 Tahun Bustanul Arifin. Jakarta: Ikaha Jakarta, 1994.

Bisri, Cik Hasan. Peradilan Islam dalam Tatanan Masyarakat Indonesia. Cet. Bandung : Renaja Rosdakarya, 1997.

Derobi, Muhammad. Analisis UU No. 7 Tahun 1989, UU No. 3 Tahun 2006 dan UU No. 50 Tahun 2009. Makalah UIN Syarif Hidayatullah, Jumat 24 Mei 2013.

Daulay, Sayuruddin. Positivisasi Hukum Islam di Indonesia dalam Perspektif Politik Hukum (AnalisaTerhadap Hukum Perkawinan). Medan: Tesis Program Pasca Sarjana UMSU, 2006.

Fahimah, Iim. Sejarah Perkembangan Hukum Waris di Indonesia. Jurnal Nuansa Vol. XI, No. 2, Desember 2018.

Hamimi, Taufiq. Ikhtisar Sejarah Peradilan Agama di Indonesia. Mimbar Hukum, No. 59 Thn. XIV, 2003.

Hazairin. Hukum Kewarisan Bilateral Menurut Al-Qur'an dan Hadis. Jakarta: Tintamas, 1981.

Irsyad, Syamsuhadi. Eksistensi Peradilan Agama Pasca UU. No. 3 Tahun 2006. Medan: Makalah dalam Acara Sosialisasi UU No. 3 Tahun 2006 tentang Perubahan atas UU No. 7 Tahun 1989 tentang Peradilan Agama, pada tanggal 22-23 Desember 2006.

Ibrahim, Malik. Peradilan Agama di Era Orde Baru dan Reformasi Suatu Studi Perbandingan. Jurnal: Supremasi Hukum Vol. 4, No. 2, Desember 2015. 
Jamil, Jamal. Peradilan Agama di Indonesia Historya of Existence. Jurnal AlQada'u: Peradilan dan Hukum Keluarga Islam, Vol. 5 No. 1 Juni 2018.

Jaspan, M.A. Mencari Hukum Baru Sinkretisme Hukum di Indonesia yang Membingungkan, dalam Mulyana W. Kusumah (ed), Hukum Politik dan Perubahan Sosial. Jakarta: Yayasan Lembaga Bantuan HUkum Indonesia, 1988.

Kementerian Agama RI. Problematikan Hukum Kewarisan Islam Kontemporer di Indonesia. Cet. I; Jakarta: Badan Litbang dan Diklat Puslitbang Kehidupan Keagamaan, 2012.

Noer, Daliar. The Modernist Muslim Movement in Indonesia 1900-1942. London: KL: 1973.

Nuzul, Andi. Sistem Hukum Kewarisan Bilateral Hazairin dan Pengaruhnya terhadap Pembaruan Hukum Kewarisan di Indonesia. Cet. I; Yogyakarta: Trussmedia Grafika, 2018.

Ramly, Mohd. Abdu A. Kedudukan Peradilan Agama dalam Sistem Hukum Nasional (Akar, Sejarah, dan Perkembangannya). Jakarta: Jurnal: Mimbar Hukum No. 59/2003.

Rasyid, Chatib. Eksistensi Peradilan Agama Pasca UU No. 3 Tahun 2006. Medan: Makalah dalam Kuliah Umum Acara Peresmian/pengukuhan Pengurus Ikatan Keluarga Magister Ilmu Hukum UMSU, 2007.

Rosyadi, A. Rahmad dan M. Rais Ahma. Formaolasi Syari'at Islam dalam Perspektif Tata Hukum Indonesia. Bogor : Ghalia Indonesia, 2006.

Rahardjo, Satjipto. Pengadilan Agama Sebagai Pengadilan Keluarga, dalam Amrullah et.al. (ed), Prospek Hukum Islam dalam Kerangka Pembangunan Hukum Nasioal di Indonesia. Jakarta: PP. IKAHA, 1994.

Ash-Shiddieqy, Hasbi. Fiqhul Mawaris. Jakarta: Bulan Bintang, 1973.

Saekan dan Erniati Effendi. Sejarah Penyusunan Kompilasi Hukum Islam di Indonesia. Surabaya : Arkola, 1997.

Sjadzali, Munawir. Dari Lembah Kemiskinan, dalam Muhammad Wahyuni Navis (ed.), Kontektualisasi Ajaran Islam. Jakarta: Paramadina, 1995.

Taufiq, H. Prospek Peradilan Agama. Makassar: Makalah Seminar Nasional dan Kongres I Forum Mahasiswa Syari'ah Se Indonesia, 1996.

Undang-Undang Dasar Negara Kesatuan RI Tahun 1945

Undang-Undang No. 14 Tahun 1970 tentang Ketentuan-Ketentuan Pokok Kekuasaan Kehakiman.

Undang-Undang No. 7 Tahun 1989 tentang Peradilan Agama

Undang-Undang No. 4 Tahun 2004 tentang Kekuasaan Kehakiman

Undang-Undang No. 10 Tahun 2004 tentang Pembentukan Peraturan PeundangUndangan

Undang-Undang No. 3 Tahun 2006 tentang Peradilan Agama

Undang-Undang No. 48 Tahun 2009 tentang Kekuasaan Kehakiman

Undang-Undang No. 50 Tahun 2009 tentang Peradilan Agama

UU No. 12 Tahun 2011 tentang Pembentukan Peraturan Peundang-Undangan

Wignyodipoero, Soeroyo. Pengantar dan asas-Asas Hukum Adat. Jakarta: Gunung Agung 1995. 